\title{
Nasionalisme Kebangsaan Sebagai Spirit Perjuangan Tokoh Pejuang di Lombok Timur 1945-1949
}

\author{
Abdul Rasyad ${ }^{1}$, Badarudin'2, Lalu Murdi ${ }^{3}$, Jujuk Ferdianto ${ }^{4}$ \\ 1,2,3Fakultas Ilmu Sosial dan Ekonomi Universitas Hamzanwadi \\ ${ }^{4}$ Politeknik Pariwisata Negeri Lombok \\ Email: rasyad.iis@hamzanwadi.ac.id, badarudin@hamzanwadi.ac.id, \\ lalumurdi@hamzanwadi.ac.id, jujuk.ferdianto@ppl.ac.id.
}

\begin{abstract}
The struggle of the Indonesian people to achieve independence from the colonialists is as old as colonialism itself. The struggle for independence had at least begun since the establishment of the late 19th century as a chain of struggle for the people in various regions in the archipelago. The struggle of the people of East Lombok in opposing colonialism is a historical record that complements the history of the national struggle of the Indonesian nation and does not have any meaning for the national struggle of the nation. This research is a historical research, therefore the stages of the historical method are carried out through heuristics, criticism, interpretation, and historiography.. The results showed that study has a fundamental contribution in understanding historical information related to nationalism and the spirit of struggle for warriors in East Lombok. History, in this case the revolution in East Lombok in 1945-1949, has a dedactic value for the current and future generations of the nation. The educational value that can be learned from these historical events is at least that the nation's generation has mental strength both biologically and psychologically in facing all the challenges of life and has a high sense of nationalism as part of Indonesian society that must uphold the name of the Indonesian nation.
\end{abstract}

Keywords: Nationalism, Nationality, Struggle.

\begin{abstract}
Perjuangan bangsa Indonesia untuk mewujudkan kemerdekaan melepaskan diri dari hisapan penjajah sama usianya dengan penjajahan itu sendiri. Perjuangan kemerdekaan paling tidak sudah dimulai sejak berdirinya akhir abad ke-19 sebagai mata rantai perjuangan rakyat di berbagai daerah di Nusantara. Perjuangan rakyat Lombok Timur dalam menentang penjajahan merupakan catatan sejarah yang melengkapi sejarah perjuangan nasional bangsa Indonesia dan tidak kecil artinya bagi perjuangan bangsa secara nasional. Penelitian ini merupakan penelitian sejarah, karena itu tahapan metode sejarah dilakukan melalui heuristik, kritik, interpretasi, dan historiografi. Hasil penelitian menunjukkan bahwa studi ini memiliki kontribusi mendasar dalam memahami informasi kesejarahan yang berkaitan dengan nasionalisme kebangsaan dan spirit perjuangan tokoh pejuang di Lombok Timur. Sejarah dalam hal ini peristiwa revolusi di Lombok Timur tahun 1945-1949 tersebut memiliki nilai dedaktis untuk generasi bangsa saat ini dan akan datang. Nilai pendidikan yang dapat dipelajari dari peristiwa sejarah tersebut paling tidak dapat bahwa generasi bangsa memiliki kekuatan mental baik secara biologis maupun psikologis dalam menghadapi segala tantangan hidup yang ada dan memiliki rasa nasionalisme yang tinggi sebagai bagian dari masyarakat Indonesia yang harus menjunjung tinggi nama bangsa Indonesia..
\end{abstract}

Kata kunci : Nasionalisme, Kebangsaan, Perjuangan. 


\section{PENDAHULUAN}

Perjuangan rakyat Indonesia untuk mewujudkan dan mempertahankan kemerdekaan termasuk di Lombok Nusa Tenggara Barat terus dilakukan. Dalam sejarah nasional tercatat perlawanan bersenjata rakyat Lombok pada tahun 1894 terhadap penjajah Belanda dengan tewasnya Wakil Panglima tentara Belanda Mayor Jenderal P.P.H. Van Ham yang kuburannya masih bisa disaksikan di Cakranegara Lombok Barat. Sejak peristiwa itu mulai tahun 1894-1942 dengan resmi pulau Lombok menjadi daerah jajahan Hindia Belanda.

Khusus di daerah Lombok Timur juga muncul perlawanan rakyat terhadap penjajah Belanda seperti; perang Gandor tahun 1895, perang Pringgabaya I tahun 1911, dan perang Pringgabaya II tahun 1913 (Salam \& Jaya, 2005). Perlawan rakyat juga terjadi di Brang Panas, Desa Kembang Kuning pada tanggal 11 Desember 1945. Di Desa Wanasaba laskar rakyat menyerbu tentara pendudukan Jepang pada tanggal 17 Desember 1945. Memasuki tahun 1946 markas tentara Jepang di Labuhan Haji di serang oleh rakyat. Pada periode berikutnya perlawanan rakyat Lombok Timur terhadap Netherland Indies civil Administration (NICA) yang membonceng pasukan sekutu (Inggris) meledak pada pertempuran 7 Juni 1946 di Kota Selong sebagai markas Gajah Merah.

Peristiwa-peristiwa ini memberikan gambaran bahwa perjuangan menentang penjajahan di pulau Lombok untuk mencapai kemerdekaan bangsa berlangsung dalam kurun waktu yang lama. Perjuangan ini merupakan peristiwa heroik yang menjadi peletak dasar bagi berdiri tergaknya Negara Kesatuan Republik Indonesia. Pada masa akhir penjajahan Belanda yang beralih ke masa pendudukan Jepang sampai 
pada revolusi fisik upaya perlawanan semakin tinggi dan kaum muda masa itu tidak mau kalah dari pendahulunya dalam perjuangan.

Perjuangan rakyat Lombok Timur dalam menentang penjajahan merupakan catatan sejarah yang melengkapi sejarah perjuangan nasional bangsa Indonesia dan tidak kecil artinya bagi perjuangan bangsa secara nasional. Perjuangan ini juga merupakan ikatan yang sangat kuat bagi tercapainya perjuangan yaitu Proklamasi Kemerdekaan 17 Agustus 1945, serta usaha mempertahankan kemerdekaan Indonesia sampai tahun 1950. Keberhasilan perjuangan dilandasai oleh jiwa, semangat dan nilai-nilai perjuangan untuk mewujudkan cita-cita nasional yang bersifat terus menerus, berlanjut, dan tidak ada akhirnya. Dalam perjuangan selalu diperlukan jiwa semangat dan nilai-nilai kejuangan sebagai landasan, kekuatan, dan daya dorong perjuangan, yaitu nasionalisme kebangsaan.

Nasionalisme kebangsaan ini menjadi gagasan utama dalam studi ini. Dalam kaitan inilah studi spirit tokoh sejarah lokal Lombok Timur dan riwayat perjuangannya terutama pada masa revolusi fisik tahun 1945-1949 sangat penting untuk dilakukan. Studi ini dimaksudkan tidak hanya membahas tentang perjuangan saja, tetapi dimaksudkan sebagai upaya untuk menghargai dan menghormati jasa-jasa mereka, menanamkan semangat persatuan dan kesatuan bangsa, membangkitkan kebanggaan nasional dan daerah, melestarikan jiwa dan semangat kepahlawanan dalam hidup berbangsa dan bernegara. Di samping itu juga studi ini dimaksudkan untuk mengungkapkan kisah kehidupan para tokoh pejuang yang berguna sebagai suri tauladan bagi generasi penerus demi kesinambungan perjuangan bangsa dan negara dalam mengisi kemerdekaan dalam konteks nasionalisme kebangsaan. 
Konsep revolusi merujuk pada suatu pengertian tentang perubahan sosial politik yang radikal, berlangsung cepat dan besar-besaran. Hal itu berbeda dengan konsep evolusi yang lebih mengacu pada perubahan yang berlangsung secara perlahan-lahan, tetapi pasti (Supardan, 2010, p. 342). Mengacu pada konsep tersebut, perjuangan cepat dan besar-besaran yang dilakukan oleh pejuang Lombok Timur dalam mempertahankan kemerdekaan Republik Indonesia antara tahun 1945-1950 jelas merupakan perubahan yang revolusioner. Konsep kemerdekaan atau kebebasan adalah nilai utama dalam kehidupan politik bagi setiap negara dan bangsa maupun umat manusia yang senantiasa diagung-agungkan, sekalipun tidak selamanya dipraktikkan. Arti penting kemerdekaan ini dapat dilihat pada ketentuan yang mengatur hak-hak asasi manusia, sebagaimana tercantum dalam Deklarasi Hak-Hak Manusia Universal yang disetujui dengan suara bulat oleh Majelis Perserikatan BangsaBangsa tanggal 10 Desember 1948 (Supardan, 2010, pp. 340-341). Dalam kehidupan berbangsa dan bernegara, konsep kemerdekaan ini lebih menitikberatkan pada komitmennya untuk menentukan nasibnya sendiri sebagai bangsa yang berdaulat dan tidak terikat oleh bangsa dan negara mana pun, termasuk penjajah sekalipun.

Konsep nasionalisme secara sederhana memiliki arti rasa kebangsaan, dimana kepentingan negara dan bangsa mendapat perhatian besar dalam kehidupan bernegara. Bahkan, menurut Kenneth Minogue, nasionalisme merupakan keyakinan bahwa pada hakikatnya setiap bangsa memiliki hak dan kewajiban untuk membentuk dirinya sebagai negara (Minogue, 2000, p. 695). Nasionalisme muncul sebagai gagasangagasan romantik tentang kemanusiaan yang mendalam pada sosial 
budayanya yang khas, telah menimbulkan kekaguman nostalgia masa lalu yang jaya tentang kemajuan-kemajuan ekonomi dan seni budaya yang dipahami sebagai pengejawantahan jiwa nasional telah mendorong bangkitnya nesionalisme (Supardan, 2010, p. 340). Ide tentang nasionalisme di Indonesia telah menjadi perdebatan dan perbenturan, berlangsung sangat panjang, terkadangan terasa hangat, memanas, melelahkan, disebabkan karena "Nasionalisme adalah suatu 'agama baru' bagi kaum cendekiawan pada awal abad sampai pertengahan abad dua puluh di Indonesia" (Daniel Dhakidae, 2001, p. xvi). Nasionalisme Indonesia disebarkan dengan susah payah oleh kaum terdidik kepada rakyat Indonesia sebagai proses pendidikan politik yang terpenting dalam sejarah nasionalisme kebangsaan Republik Indonesia (Anwar, 2014, pp. 150-172).

Studi tentang sejarah perjuangan di Lombok sudah banyak dilakukan di antaranya studi tentang "Nahdlatul Wathan dan Perjuangan TGKH. Muhammad Zainuddin Abdul Madjid (1908-1997)" (Fattah et al., 2017), studi tentang "Pemberontakan Gandor 1895: Sebuah Perlawanan Kaum Sufi Terhadap Kekuasaan" (Salam \& Jaya, 2005), studi tentang “Sejarah Daerah Nusa Tenggara Barat (Wacana, 1988)", studi "Sejarah Kebangkitan Nasional Nusa Tenggara Barat" (Wacana et al., 1991), dan studi tentang "Sejarah Revolusi Kemerdekaan, 1945-1949 Daerah Nusa Tenggara Barat" (Kutoyo, 1980). Studi yang telah dikemukakan di atas secara umum lebih banyak menggambarkan tentang Sejarah Lombok dalam periode tertentu dengan kajian yang secara khusus tidak ada yang menjelaskan tentang nasionalisme yang tumbuh dan berkembang di Lombok pada masa penjajahan, baik oleh Bali Karangasem, Belanda, dan 
Jepang. Keberbedaan dengan studi ini terletak pada semangat dan bangunan nasionalisme yang secara historis telah tumbuh dan berkembang pada jiwa para pejuang sehingga tumbuh tekad untuk berjuang melawan Belanda. Berdasarkan hal tersebut studi ini memiliki kontribusi mendasar dalam memahami informasi kesejarahan yang berkaitan dengan tokoh pejuang di Lombok Timur. Studi ini diharapkan dapat memberikan refleksi perjuangan pahlawan dari Lombok Timur, bermanfaat untuk membangun karakter kebangsaan dan rasa nasionalisme.

\section{METODE}

Metode yang digunakan dalam studi adalah metode sejarah. Mengkaji masa lalu, sekaligus di dalamnya jelas mengenai konsep "kapan" dan "sampai bila" dari sebuah peristiwa, pencariannya harus menggunakan metode sejarah (Abdullah \& Surjomihardjo, 1985). Landasan utama penggunaan metode sejarah terkait strategi penanganan bukti-bukti sejarah dan bagaimana menghubungkannya (Frederick \& Soeroto, 2005). Heuristik merupakan langkah awal sebagai sebuah kegiatan mencari sumber-sumber, mendapatkan data, atau materi sejarah atau evidensi sejarah (Sjamsuddin, 2007, p. 86). Beragam jenis dokumen yang dapat digunakan untuk dapat merekonstruksi jejak sejarah perjuangan tokoh pejuang di Lombok seperti; dokumen Legium Veteran di Lombok Timur, Sertifikat, Surat Perintah, Catatan-catatan masa pemerintahan Belanda dan Jepang, dokumen resmi perjuangan pada masa revolusi fisik, surat-surat kabar, notulen, dan lain sebagainya yang masih ada. Begitu juga halnya dengan sertifikat, catatan organisasi dan lain-lain. 
Data juga didapatkan melalui wawancara terhadap beberapa informan yang mengetahui peristiwa yang diteliti.

Data yang terdapat dalam bahan dokumen tidaklah secara khusus tersedia bagi studi sejarah, tetapi ilmu sejarah dapat meminjam fenomenon dalam masyarakat yang mempunyai dimensi temporal. Bahan dokumenter dalam mengkonstruksi konseptual dan teoritis akan mempertinggi potensi heuristik dan memperbaiki tata metodologisnya (Kartodirdjo, 1982, pp. 130-160). Sumber-sumber yang digunakan juga beberapa buku hasil studi mendalam seperti penulisan beberapa buku yang dilakukan Proyek Inventarisasi dan Dokumentasi Kebudayaan Daerah oleh Depdikbud berkaitan dengan sejarah masyarakat SasakLombok dan artikel jurnal ilmiah. Sumber wawancara juga dilakukan kepada tokoh-tokoh yang mengetahui peristiwa yang menjadi obyek penelitian. Proses selanjutnya yang dilakukan adalah kritik sumber melalui kritik eksternal dan kritik internal. Selanjutnya dilakukan analisis atau interpterasi. Dalam tulisan sejarah, digunakan secara bersamaan tiga bentuk teknis dasar tulis-menulis yaitu deskripsi, narasi, dan analisis (Sjamsuddin, 2007, p. 132). Tahapan terakhir adalah historiografi di mana penulisan sejarah dilakukan dengan ungkapan bahasa sehari-hari untuk dapat dan mudah dimengerti oleh pembaca, urutan periodisasi untuk melihat kesatuan sejarah, menyajikan bukti-bukti dan membuat garisgaris umum untuk dapat dengan mudah dipahami (Abdurrahman, 1999).

\section{HASIL DAN PEMBAHASAN}

Nasionalisme Tokoh Pejuang Lombok Timur 1945-1949

Pada tanggal 29 September 1945 tentara sekutu mendarat di Jakarta. Kemudian pada tanggal 25 Oktober 1945 pasukan Allied Forces Netherlands 
East Indies (AFNEI) mendarat di Tanjung Perak, Surabaya. Pendaratan AFNEI di Surabaya dengan kapal perang Eliza Thomposon di bawah pimpinan Brigadir Jenderal A.W.S Mallaby (Welianto, 2020). Pada pertempuran Surabaya yang mencapai puncaknya pada tanggal 10 November 1945 yang kemudian dikenal sebagai hari Pahlawan Nasional adalah puncak dari serentetan peristiwa serta insiden antara rakyat Surabaya dengan tentara Inggris yang mendarat di Surabaya sejak 25 Oktober 1945 (Moehkardi, 2019).

Sedangkan di Lombok tentara sekutu yang dibonceng oleh NICA mendarat di Ampenan pada tanggal 18 Maret 1946 dan di Lembar pada tanggal 27 Maret 1946. Sebelumnya NICA tentara sekutu (Australia) telah lebih dahulu mendarat di Ampenan yaitu pada tanggal 30 Nopember 1945 dengan memakai lencana merah putih untuk melucuti tentara Jepang dan senjata mereka dibuang ke laut. Sejak kedatangan tentara NICA, Raden Nuna Noeraksa selaku Kepala Daerah Lombok dapat dibujuk oleh NICA dan berbalik memusuhi rakyat bahkan sempat juga dikatakan bahwa para pejuang seperti, Sayyid Saleh dan Haji Muhammad Faesal dikatakan sebagai perusuh karena perbuatannya dalam memimpin rakyat untuk melawan pasukan NICA (Wacana, 1988; Wacana et al., 1991).

Menyerahnya Jepang kepada Sekutu tidak didengar beritanya oleh rakyat Lombok Timur. Bahkan proklamasi tanggal 17 Agustus 1945, baru diketahui secara meyakinkan pada pertengahan bulan September 1945 setelah beberapa orang pelajar yang berasal dari Sumbawa, Bima pulang dari Jawa dan mereka singgah di Lombok dan memberikan informasi tentang peristiwa Proklamasi Kemerdekaan RI 1945 yang dibacakan oleh Soekarno-Hatta. Persinggungan pelajar asal Lombok, Sumbawa, dan Bima 
inilah yang membawa benih nasionalisme sebagai buah pergulatan pemikiran yang mereka alami selama menempuh pendidikan di Jawa.

Pernyataan di atas tidak sepenuhnya dibenarkan karena beberapa sumber menyebutkan bahwa seorang tokoh di Pringgasela yaitu TGH Muhammad Thoyib merupakan orang yang sudah tahu tentang Proklamasi Kemerdekaan Republik Indonesia. Hal ini dijelaskan oleh Muhammad Zainuddin bahwa:

"Bapak Tuan Guru Muhammad Thoyib adalah tokoh yang banyak tau tentang peristiwa Proklamasi Kemerdekaan RI 1945. Beliau sering ke Surabaya melakukan hubungan dagang sebelum peristiwa kemerdekaan. Selama di Surabaya di samping beliau berdagang, beliau juga berinteraksi dengan tokoh-tokoh pergerakan nasional disana. Bahkan beliau yang pertama kali membawa PSI ke Lombok" (Wawancara tanggal 26 Juni 2016).

Penjelasan di atas dapat dijadikan rujukan bahwa beberapa masyarakat Lombok sudah ada yang tahu peristiwa Proklamasi 17 Agustus 1945. Hal ini juga diperkuat dengan kondisi di mana menjelang penyerangan NICA tahun 1946 di Pringgasela menjadi sentral koordinasi sebelum penyerangan dilakukan. Pernyataan di atas juga menguatkan tentang jiwa nasionalisme yang sudah tumbuh pada tokoh pejuang Lombok Timur sebagai spirit perjuangan dalam melawan penjajah.

Walaupun rakyat Lombok terlambat mengetahui kemerdekaan bangsa Indonesia, tetapi setelah itu semangat pemuda berkobar. Rapatrapat umum untuk mengumumkan proklamasi kemerdekaan Indonesia kemudian diadakan tanggal 15 Oktober 1945 di Mataram, tanggal 16 Oktober di Praya, dan tanggal 17 Oktober 1945 di Selong. Dalam situasi memuncaknya perlawanan rakyat terhadap Jepang sekitar bulan November dan Desember 1945 sering berlangsung pertemuan antara 
pimpinan perjuangan di daerah Lombok. Tercatat pertemuan di Dasan Tengah Desa Montong Gamang Kabupaten Lombok Tengah. Pertemuan ini berusaha menyatukan sikap dan langkah dalam menghadapi tindakan Jepang pada waktu itu.

Di Lombok Timur perlawanan terhadap Jepang meledak dengan terjadinya pertempuran di Brang Panas Desa Kembang Kuning pada tanggal 11 Desember 1945. Dengan bersenjatakan tradisional seperti keris, kelewang, golok, dan bambu runcing, pasukan laskar pemuda yang dipimpin oleh Sayyid Saleh dengan kekuatan sekitar 85 orang menyerbu markas tentara Jepang di Brang Panas. Dalam pertempuran di Barang Panas, telah gugur 5 (lima) orang pejuang pahlawan bangsa yaitu: Bapak Hawa, Bapak Minah, dan Bapak Muhammad dari Pringgasela, Bapak Salamah dari Rempung dan Alam dari Penyaong. Kelima pahlawan bangsa ini dimakamkan di Taman Makam Pahlawan Rinjani Selong.

Di Desa Wanasaba, I peleton tentara Jepang yang ditempatkan di Desa tersebut diserbu oleh rakyat pada tanggal 17 Desember 1945. Ratusan rakyat yang dipimpin oleh laskar rakyat, dari Desa Mamben dengan semangat yang menyala-nyala dan dengan keberanian yang luar biasa menyerbu tentara Jepang yang menggunakan senjata mesin. Peristiwa perlawanan rakyat di Desa Wanasaba tersebut kurang menguntungkan bagi laskar rakyat, karena persenjataan yang sangat sederhana serta pertempuran yang terjadi di luar desa, sangat tidak strategis bagi laskar rakyat yang hanya bersenjatakan pedang dan tombak pada waktu itu. Akibatnya 6 pejuang telah gugur dalam penyerbuan di Desa Wanasaba tersebut adalah: Haji Thahir, Haji Samsudin, Amaq Zainur, Amaq Zahrah, Amaq Sapinah, dan Amaq Muadah. 
Memasuki tahun 1946, pada bulan Januari Desa Labuhan Haji, Tanjung Teros, Kelayu, Selong, Pancor, Rempung, Penyaong, Pringgasela,Lenek, Suralaga, Dasan Lekong dan lain-lainya , melakukan penyerbuan ke markas tentara Jepang, dalam penyerbuan ini ,laskar rakyat berhasil memperoleh senjata, 3 pucuk keraben, 5 pucuk pistol, dan 17 peti peluru. Akan tetapi beberapa waktu kemudian datangnya tentara NICA, hasil rampasan tersebut diambil kembali oleh NICA.

Tokoh pejuang Lombok Timur yang berperan penting dalam perlawanan terhadap NICA tahun 1946 adalah Sayyid Saleh dari Pringgasela dan Tuan Guru Haji (TGH) Muhammad Faeshal dari Pancor. Sayyid Saleh merupakan tokoh sentral yang banyak memberikan arahan dan koordinasi sebelum penyerangan NICA tanggal 7 Juni 1946. Kedekatan Sayyid Saleh dengan tokoh kharismatik dari Pringgasela, yaitu Tuan Guru Haji (TGH) Muhammad Thoyib telah memberikan kesadaran akan arti penting perjuangan melawan penjajah (NICA). Diketahui bahwa TGH Muhammad Thoyib sudah lama melakukan kontak dengan tokohtokoh pejuang dari Surabaya. Hal ini diketahui lewat kontak antara pedagang dari Masbagik dan Pringgasela yang melakukan hubungan dagang ke Jawa (Wawancara dengan Muhammad Zainuddin, 26 Juni 2016). Disela-sela hubungan dagang inilah didapatkan informasi tentang gerakan nasionalisme dan perjuangan tokoh pejuang di Surabaya. Menurut Muhammad Zainuddin dari sinilah kemudian terjadi persinggungan tentang semangat nasionalisme dan pentingnya perjuangan mempertahankan kemerdekaan. Tumbuhnya nasionalisme pada tokoh pejuang Lombok Timur merupakan lompatan berpikir yang digaungkan oleh TGH Muhammad Thoyib dan TGH Muhammad 
Zainuddin Abdul Madjid yang diteruskan pada Sayyid Saleh dan TGH Muhammad Faishal berserta rekan-rekan seperjuangannya. Kedua tokoh ini kemudian menjadi figur sentral yang memberikan semangat juang dan perlawanan terhadap kekuasaan NICA di Lombok Timur.

TGH Muhammad Faishal merupakan adik kandung TGH Muhammad Zainuddin Abdul Madjid, seorang tokoh ulama karismatik yang dikenal luas sebagai pendiri madrasah pertama di Lombok yang menggunakan sistem klasikal yaitu, madrasah Nahdlatul Wathan Diniyah Islamiyah (NWDI) khusus untuk laki-laki dan madrasah Nahdlatul Banat Diniyah Islamiyah (NBDI) khusus untuk perempuan (Fattah et al., 2017). Jiwa nasionalisme tokoh ini muncul dari sang kakak yang memang dikenal luas sebagai seorang pejuang terutama dalam aspek pendidikan dan dakwah.

Sebelum penyerangan dilakukan tanggal 7 Juni 1946, koordinasi dilakukan di Pringgasela. Beberapa tokoh melakukan pertemuan di rumah TGH. Muhammad Thoyib. Hal ini sebagaimana dijelaskan oleh Muhammad Zainuddin bahwa:

Sayyid Saleh mengatakan kepada TGH. Muhammad Thoyib bahwa dia dan rekan-rekannya sudah siap melakukan penyerangan ke Selong untuk melawan tentara NICA. TGH. Muhammad Thoyib sempat melarang karena pertimbangan kondisi yang belum memungkinkan. Tetapi karena Sayyid Saleh dan rekan-rekannya sudah tidak dapat dicegah, maka beliau merestui penyerangan (Wawancara tanggal 26 Juni 2016).

Menurut Muhammad Zainuddin, pertemuan-pertemuan tokoh pejuang Lombok Timur dengan TGH Muhammad Thoyib sebelumnya sudah sering dilakukan untuk membicarakan persiapan menyerang markas NICA di Selong. Pada pertemuan-pertemuan inilah sering 
disampaikan tentang arah dan gerakan perjuangan tokoh pejuang lainnya di Jawa. Selama proses interaksi ini kemudian menumbuhkan sikap nasionalisme untuk membela bangsa dan negara mempertahankan proklamasi kemerdekaan Indonesia tanggal 17 Agustus 1945 (Wawancara tanggal 26 Juni 2016).

Peristiwa ini juga ditegaskan oleh kedatangan TGH. Muhammad Faesal adik TGH. Muhammad Zainuddin Abdul Madjid ke Pringgasela untuk ikut melakukan koordinasi dengan pejuang yang lain dalam persiapan penyerangan ke Selong sebagai markas NICA (Wawancara dengan TGH. Zainuddin tanggal 26 Juni 2016). Menurut TGH. Zainuddin, rencana penyerangan yang akan dimulai dari Lendang Nangka Masbagik sudah diberitahukan kepada TGH. Muhammad Zainuddin Abdul Madjid. Begitu pula dengan di Lendang Nangka, pejuang-pejuang yang berjumlah 7 (tujuh) orang sudah siap berangkat. Pertemuan para pejuang nanti dilakukan di perjalanan sampai di Danger (Wawancara dengan L. Darwita, tanggal 24 Juni 2016).

Penyerangan dimulai pada Juni 1946, dimana sepasukan rakyat dibawah pimpinan Sayyid Saleh, Haji Muhammad Faesal dan Abdullah, dengan persenjataan yang sangat sederhana menyerbu tangsi militer Belanda di Selong. Dalam penyerbuan itu ketiga pejuang tersebut gugur dan kuburannya dijadikan Taman Bahagia. Serangan ini mengalami kegagalan karena sudah diketahui oleh kaki tangan NICA. Demikian pula sebagian rakyat dipengaruhi dengan dalih bahwa laskar pemuda pejuang adalah gerombolan perampok yang akan merampok kota Selong dari berbagai penjuru. Dari kegagalan serangan itu, maka pimpinan-pimpinan laskar pejuang rakyat mulai mengatur siasat. Taktik dan siasat diubah 
dengan cara gerilya. Penyerbuan harus melalui rute yang aman dari kaki tangan penjajah. Dengan kesepakatan para pejuang yang bergabung dalan laskar rakyat. Penyerbuan untuk kedua kalinya dilakukan ke markas tentara Belanda di Kota Selong yang dilaksanakan pada tanggal 7 Juni 1946. Sayyid Saleh, pemimpin pemuda pejuang dari Desa Pringgasela pada sore hari tanggal 7 Juni 1946 tersebut, bergabung dengan para pemuda pejuang dari Lendang Nangka, Danger, dan Dasan Lekong serta seluruh daerah yang tergabung dalam kelaskaran. Keseluruhan pemuda pejuang itu bergabung dengan para pejuang di bawah pimpinan Haji Muhammad Faesal di Bumbasari, sebelah selatan kota Selong.

Penyerbuan markas tentara Belanda di Kota Selong (sekarang gedung juang 45) pada tanggal 7 Juni 1946 merupakan pertempuran yang tidak seimbang, karena para pemuda pejuang hanya bersenjatakan kelewang, golok, bambu runcing disertai dengan jiwa dan semangat juang yang tinggi dan rasa cinta tanah air untuk mengusir penjajah dari bumi ibu pertiwi. Tidak ada pilihan lain dari para pejuang dengan semboyan merdeka atau mati daripada dijajah itulah pikiran para pejuang. Dengan mengumandangkan bacaan takbir mereka pemimpin-pemimpin pejuang memasuki markas Belanda, dan membangunkan tentara Gajah Merah, karena jiwa kesatria para pejuang yang tidak akan membunuh musuh dalam keadaan tidur.

Ada yang menarik dengan dibacakannya "takbir" dari para pejuang ini. Sebagai sebuah strategi perang, logikanya para pejuang tidak melakukan penyerangan dengan terang-terangan. Tetapi oleh Sayyid Saleh dikatakan "kita harus menyerang musuh yang terbangun/terjaga, tidak boleh kita membunuh musuh dalam keadaan tidur". Karena itulah 
pekikan "takbir" dilakukan oleh para pejuang (Wawancara dengan Muhammad Zainuddin, tanggal 26 Juni 2016). Hal ini penting menjadi catatan bahwa ini menunjukkan bahwa para pejuang adalah orang yang menghormati etika dalam peperangan. Hal ini patut menjadi teladan bagi generasi penerus sekarang ini.

Pertempuran berlangsung dengan sangat cepat, hanya dalam waktu sekitar 15 menit karena keterbatasan persenjataan, para pejuang mengundurkan diri. Dalam pertempuran tersebut, 8 orang tentara Belanda tewas, sedangkan para pejuang yang gugur sebanyak 3 orang. Ketiga pejuang ini telah menjadi martil dari suatu pergolakan rakyat dalam mengusir penjajah. Ketiga pejuang yang gugur tersebut adalah Sayyid Saleh, TGH Muhammad Faesal dan Abdullah. Darah mereka telah meresap dalam tanah dimana sekarang ini berdiri Gedung Juang 45 yang merupakan sebuah gedung yang bersejarah di Lombok Timur. Setelah peristiwa 7 Juni 1946 yang dapat dikatakan gagal, tentara NICA mulai mengadakan pembersihan dengan melakukan penangkapanpenangkapan terhadap para pemuda pejuang terutama tokoh-tokoh yang berasal dari Pringgasela. Dijelaskan oleh Muhammad Zainuddin bahwa setelah peristiwa penyerangan itu banyak tokoh yang ditangkap, termasuk TGH. Muhammd Thoyib sempat didatangi oleh tentara NICA ke rumahnya di Pringgasela (Wawancara tanggal 26 Juni 2016). Ada yang menarik dari peristiwa ini, yaitu tentang diketahuinya beberapa tokoh yang dianggap turut terlibat paling tidak mengetahui peristiwa penyeranan. TGH Muhammad Thoyib dan TGH Muhammad Zainuddin Abdul Madjid sempat diperiksa oleh NICA. Hal ini juga menandakan 
bahwa ada pengkhianat yang memberikan informasi kepada pemerintah NICA di Selong.

\section{Refleksi Nasionalisme Kebangsaan dalam Perjuangan Revolusi Fisik di Lombok Timur}

Kesadaran Nasionalisme para tokoh pejuang di Lombok Timur terutama pada masa Revolusi Fisik seperti gambaran sebelumnya disebabkan oleh adanya banyak saluran, mulai dari pendidikan, perdagangan dan tentu saja melalui saluran politik dan organisasi yang dibangun dengan adanya kontak dengan para tokoh pejuang di daerah lainnya termasuk yang ada di Jakarta. Kesadaran nasionalisme sehingga para pejuang semisal Sayid Saleh, Tuan Guru Muhammad Faesal, Mamiq Rafaah, Mamiq Muhammad, dan para pejuang lainnya dan tentu saja keberadaan TGKH Muhammad Zainuddin Abdul Madjid yang terus mengorbankan semangat juang sama halnya dengan semangat juang yang ditularkan dalam konteks perlawanan fisik secara nasional. Oleh sebab itu, dalam konteks refleksi, dapat digeneralisasikan dengan konteks nasional juga.

Dalam usaha pencapaian kemerdekaan Indonesia berbagai cara digunakan bangsa Indonesia, mulai dari perlawanan fisik hingga perjuangan diplomatis untuk mendapat bantuan dan pengakuan dari negara lain. Korban sudah menjadi hal yang biasa dalam usaha itu, tapi menjadi tidak biasa jika bangsa Indonesia gagal memperoleh kemerdekaannya. Kondisi negara dan tepatnya waktu juga tidak dapat dilupakan dalam pencapaian revolusi ini. Walaupun ada nuansa keberuntungan, tapi kemampuan para tokoh untuk memanfaatkan waktu tersebut harus diperhitungkan. 
Sebagai peristiwa kemanusiaan, sejarah tentunya perlu memperhatikan kecenderungan kemanusiaan yang dimana pun dan kapan pun akan memiliki dua sisi yang berbeda, apabila pada awal proses perjuangan untuk mencapai kemerdekaan sampai menjelang dikumandangkannya proklamasi kemerdekaan Republik Indonesia (RI) oleh Soekarno-Hatta, tidak sedikit dari pemuda dan masyarakat serta sebagian dari pejabat publik yang skeptis dengan perjuangan tersebut. Tidak sedikit yang hanya sibuk mengurus kuliah, sibuk memperbaiki hubungan dengan Jepang yang sudah banyak menelan kekalahan dari Sekutu. Namun setelah proklamasi dikumandangkan, dengan mulainya perjuangan untuk mempertahankan kemerdekaan RI, maka dengan sendirinya masyarakat secara keseluruhan sadar bahwa kemerdekaan adalah harga mati yang harus dipertahankan secara bersama-sama.

Proklamasi dengan demikian telah mencuat dan menjadi sebuah keyakinan pada masyarakat bahwa mereka tidak lagi berusaha untuk mendapatkan kemerdekaan namun lebih dari itu adalah untuk mempertahankan kemerdekaan yang sudah jelas terlaksana. Apabila semangat perjuangan untuk mendapatkan kemerdekaan kekuatan psikologisnya masih kurang, maka dalam masa revolusi kekuatannya menjadi lebih jelas dan menyeluruh. Ada perasaan kegembiraan yang sangat dahsyat sehingga perjuangan fisik yang awalnya sebelum kemerdekaan biasanya dilakukan secara berkelompok dengan ukuran lokal yang sifatnya terbatas, kini menjadi perjuangan masyarakat Indonesia secara keseluruhan.

Kedatangan Inggris yang memboncengi NICA merupakan perjuangan revolusi dengan pilihan yang sulit di tengah membangun 
sebuah negara yang merdeka masih belia. Pilihan dan tantangan itu dilihat dengan banyaknya konflik baik secara eksternal maupun internal. Konflik tidak hanya sebatas pergulatan ideologi dan perebutan kekuasaan dalam internal pemerintahan Negara Indonesia, tapi menghadapi bahaya dari luar. Kedatangan Inggris yang memboncengi Belanda menjadi ketakutan akan munculnya sejarah kelam akan sebuah penindasan dan penderitaan. Dengan asumsi demikian maka tidak heran jika di berbagai daerah Indonesia terjadi pertempuran dan perlawanan dahsyat.

Memaknai revolusi Indonesia pada dasarnya bukan merupakan sebuah semboyan semata, tetapi lebih kepada tataran aplikasi "mau dibawa ke mana Bangsa Indonesia". Revolusi dimaknai tidak hanya dianggap sebagai sebuah gerakan ratu adil/milenari, tetapi hemat penulis Revolusi Indonesia baik dalam prespektif Bung Karno, Bung Hatta, Sutan Syahrir, dan lain sebagainya merupakan hal yang abstrak, karena revolusi merupakan sebuah konstruski apa yang sedang dipikirkan yang bersifat abstrak, tetapi anehnya berapa banyak orang yang kehilangan jiwanya hanya demi sebuah kata revolusi yang abstrak itu? Kita tidak berbicara dalam konteks pengertian makna yang benar dalam deskripsi sebuah revolusi, akan tetapi di dalamnya perlu diperhatikan adanya dinamika dalam perjuangan revolusi di Indonesia.

Revolusi dalam gerak sejarah merupakan gejala peradaban umat manusia yang harus ditafsirkan sebagai catatan masa lalu yang harus diungkap, dibicarakan, serta mengangkat hal-hal yang tabu untuk dibicarakan. Revolusi di Indonesia tidak lah serta merta ditelan mentahmentah sebagai suatu catatan ingatan, tetapi lebih dari itu. Tetapi Sejarah lebih membicarakan pada aspek makna, refleksi peristiwa yang terjadi 
pada rekaman jejak masa lalu, sehingga pola pikir analitis dalam merekonstruksi peristiwa masa lalu dalam kurun waktu revolusi Indonesia harus dikaji dalam berbagai perspektif.

Pendekatan verstehen dalam konteks ini penting juga untuk dipahami, terutama sekali berkaitan dengan indirect cause (faktor tidak langsung) yang melatarbelakangi peristiwa proklamasi di Indonesia dan di Lombok Timur pada khususnya. Apabila direct cause-nya (faktor langsung yang melatarbelakangi peristiwa sejarah) adalah keinginan Belanda untuk mempertahankan status quo, perasaan tertindas dari masyarakat, keterpurukan ekonomi, perlawanan terhadap kekerasan yang dilakukan oleh NICA dan lain sebagainya merupakan refleksi historis atas jiwa nasionalisme kebangsaan yang tumbuh dan mengakar pada setiap jiwa para pejuang. Namun yang tidak tampak dalam hal ini adalah adanya psikologi yang berbeda dari Indonesia yang sudah diproklamasikan merupakan faktor utama yang lebih kuat, sehingga semua golongan bahu-membahu untuk menuntaskan revolusi yang belum selesai tersebut.

Nasionalisme yang tumbuh sebagai hasil dari persinggungan tokoh ulama karismatik di Lombok Timur yang dibawa oleh pedagang dari Masbagik dan Pringgasela selama hubungan dagang di Jawa, telah memberikan kontribusi bagi arah dan tekad juang para pejuang di Lombok Timur untuk mengusir penjajah. Hal inilah kemudian yang menjadi penanda bahwa sikap nasionalisme itu telah tumbuh dan menjadi spirit perjuangan. Tidak mungkin para pejuang rela dan mau berkorban melakukan penyerangan ke markas tentara NICA di Selong kalau tidak dilandasi oleh semangat dan jiwa nasionalisme yang tinggi. 


\section{KESIMPULAN}

Sejarah dalam hal ini peristiwa revolusi di Lombok Timur tahun 1945-1949 tersebut memiliki nilai didaktis untuk generasi bangsa saat ini dan akan datang. Nilai pendidikan yang dapat dipelajari dari peristiwa sejarah tersebut paling tidak dapat diidentifikasi yaitu; 1) Membangun kesadaran pada generasi bangsa untuk menghargai para pejuang; 2) Generasi bangsa bangga menjadi bagian dari masyarakat Indonesia, sehingga ikut berjuang untuk membangun bangsa melalui karya yang dapat dipersembahkan; 3) Membangun kesadaran bahwa perjuangan masyarakat Indonesia untuk membebaskan diri dari penjajahan bukan merupakan hadiah dari Jepang atau Belanda, namun merupakan usaha sendiri dari bangsa Indonesia. Melalui kesadaran ini diharapkan generasi bangsa percaya diri dalam berkarya; 4). Generasi bangsa memiliki kekuatan mental baik secara biologis maupun psikologis dalam menghadapi segala tantangan hidup yang ada; dan 5). Generasi muda memiliki rasa nasionalisme yang tinggi sebagai bagian dari masyarakat Indonesia yang harus menjunjung tinggi nama bangsa Indonesia. Berdasarkan uraian tersebut jelas bahwa sejarah dalam konteks ini dapat menjadi wisdom atau pembelajaran yang bijak untuk membangun generasi muda bangsa yang lebih unggul. Sekaligus dapat dipahami bahwa sejarah merupakan peristiwa kemanusiaan yang tidak hanya mengandung hal-hal baik yang dilakukan oleh tokoh sejarah tersebut, namun juga memiliki sisi negatif yang tentunya dapat menjadi pembelajaran untuk tidak dilakukan lagi pada masa yang akan datang.

\section{DAFTAR PUSTAKA}


Abdullah, T., \& Surjomihardjo, A. (1985). Ilmu Sejarah dan Historiografi: Arah dan Perspektif. Gramedia Pustaka Utama.

Abdurrahman, D. (1999). Metode Studi Sejarah. Logos Wacana Ilmu.

Alfarisi, S., Tohri, A., Hadi, Z., Habibuddin, Hanapi, \& Rasyad, A. (2016). Tuan Guru Umar Kelayu: Poros Lombok Makkah-Nusantara. Lombok Institut, Pemerintah Daerah Lombok Timur, Kalam Semesta.

Anwar, C. (2014). Internalisasi Semangat Nasionalisme Melalui Pendekatan Habituasi (Perspektif Filsafat Pendidikan). ANALISIS: Jurnal Studi Keislaman, 14(1), 150-172.

Daniel Dhakidae. (2001). Memahami Rasa Kebangsaan dan Menyimak Bangsa sebagai Komunitas-komunitas Terbayang. In Imagined Communities: Komunitas-Komunitas Terbayang (Penerjemah Omi Intan Naomi). Pustaka Pelajar.

Fattah, A., Quddus, A., Jamaluddin, \& Muslim, M. (2017). Dari Nahdlatul Wathan untuk Indonesia: Perjuangan TGKH. Muhammad Zainuddin Abdul Madjid (1908-1997). Dinas Sosial NTB.

Frederick, W. H., \& Soeroto, S. (2005). Pemahaman Sejarah Indonesia: Sebelum dan Sesudah Revolusi. LP3ES.

Kartodirdjo, S. (1982). Pemikiran dan Historiografi Indonesia: Suatu Alternatif. Gramedia Pustaka Utama.

Kraan, A. M. van Der. (2009). Lombok: Penaklukan, Penjajahan dan Keterbelakangan, 1870-1940 (Penerjemah M. Donny Supanra). Lengge Printika.

Kutoyo, S. (1980). Sejarah Revolusi Kemerdekaan, 1945-1949 Daerah Nusa Tenggara Barat. Departemen Pendidikan dan Kebudayaan.

Minogue, K. (2000). Nasionalisme dalam Adam Kuper dan Jessica Kuper. In Ensiklopedi Ilmu-Ilmu Sosial. (Penerjemah Haris Munandar). Raja Grafindo Persada.

Moehkardi. (2019). Akademi Militer Yogya dalam Perjuangan Fisik 1945 sampai dengan 1949. Universitas Gadjah Mada Press.

Salam, A., \& Jaya, L. R. P. (2005). Pemberontakan Gandor 1895: Sebuah Perlawanan Kaum Sufi Terhadap Kekuasaan. Ulumuna, 9(1), 172-188.

Sjamsuddin, H. (2007). Metodologi Sejarah. Ombak.

Supardan, D. (2010). Pengantar Ilmu Sosial Sebuah Kajian Pendekatan 
Struktural. Bumi Aksara.

Wacana, L. (1988). Sejarah Daerah Nusa Tenggara Barat. Departemen Pendidikan dan Kebudayaan.

Wacana, L., Ismail, A. W. H., \& Sumpeno, J. (1991). Sejarah Kebangkitan Nasional Nusa Tenggara Barat. Departemen Pendidikan dan Kebudayaan.

Welianto, A. (2020). Mendaratnya Pasukan AFNEI Inggris di Surabaya. Kompas.Com.

https://www.kompas.com/skola/read/2020/06/29/190000869/mendarat nya-pasukan-afnei-inggris-di-surabaya?page=all 